\title{
CHARACTERIZATION AND GRAVITY SEPARATION OF NONSULFIDE ZINC DEPOSITS FROM UM GHEIG MINE, RED SEA COAST, EGYPT
}

\author{
M.Z. Farag ${ }^{a^{*}}$, N.A. Abdel-Khalek ${ }^{a}$, M.S. Hassan ${ }^{a}$, M.M. El \\ Areef $^{b}$, A.W. El Manawi ${ }^{b}$ \\ ${ }^{a}$ Central Metallurgical R\&D Institute (CMRDI), P.O. Box 87, Helwan, Egypt \\ ${ }^{b}$ Geology Dept., Science Faculty, Cairo University, Egypt
}

(Received December 11, 2010 Accepted December 27, 2010)

This paper aims to beneficiation of Um Gheig nonsulfide Zinc ore from its associated gangues using the gravity separation "shaking table" technique. The different operating parameters affecting of the efficiency of the separation process is evaluated.

The zinc locality of Um Gheig represents one of the important nonsulfide zinc deposits along the coastal plain of the Red Sea Coast, Egypt. These zinc ores are called "calamines" and consist mainly of a mixture of zinc carbonates (smithsonite, hydrozincite) and zinc silicates (hemimorphite), with a variable content of calcite, goethite and Pb bearing minerals.

Extensive mineralogical (using XRD, XRF) and petrographic studies have been carried out on the selected samples from Um Gheig Mine. Theses investigations show that, the nonsulfides mineral association in the deposit consists mainly of smithsonite (50.74\%), hydrozincite $(18.78 \%)$ and hemimorphite $(14.78 \%)$ replacing both primary ore minerals and carbonate host rocks. Smithsonite occurs in two generations, cryptocrystalline mixed with goethite and rhombohedral crystals, precipitate in vugs and open space of the high grade ore. The main gangue minerals are calcite and goethite. XRF analysis indicates that the sample contains $47.50 \% \mathrm{ZnO}, 1.55 \% \mathrm{PbO}$ and about $29.28 \%$ L.O.I.

Liberation and mineralogical investigation showed that higher degree of liberation (over 90\%) between the valuable zinc bearing minerals and their gangues can be achieved below the size $0.106 \mathrm{~mm}$.

The results of gravity separation showed that the best operating parameters to obtain a concentrate with high assay and recovery are at inclination angle (4 degree), stroke length $(2.5 \mathrm{~cm})$, feed rate $(150 \mathrm{gm} /$ $\mathrm{min})$, and water flow rate $(25 \mathrm{l} / \mathrm{min})$. At these optimum conditions a concentrate assaying $60.85 \% \mathrm{ZnO}$ was obtained with a recovery of $\sim 90 \%$.

KEYWORDS: Nonsulfide zinc ore, Mineralogy, Petrography, Liberation size, Gravity separation, Shaking table

\section{INTRODUCTION}

The area of Um Gheig mine is a part of the coastal plain of the Red Sea Coast, Egypt. It lies $38 \mathrm{~km}$ south of Quseir City (Fig.1). The area can be reached by Quseir-Mersa 
Alam asphalet road. The Um Gheig mine is located in Wadi Um Gheig, $7.5 \mathrm{~km}$ from the west of the Quseir -Mersa Alam asphaletic road.

Um Gheig ore is a nonsulfide $\mathrm{Zn}(\mathrm{Pb})$ deposit with estimated reserves of about two million ton with an average grade of $10 \% \mathrm{Zn}, 2 \% \mathrm{~Pb}[1,2]$. The definition of "Nonsulfide zinc" is a very general term, which comprises a large series of minerals [2-4]. The only minerals of current economic importance are ; the carbonates smithsonite and hydrozincite, and the silicates hemimorphite, willemite, as well as $\mathrm{Zn}$ smectite. The economic value of zinc nonsulfide ores is thus dependent not only on the geologic setting of each deposit but also on the specific characteristics of the mineralogical association and the nature of the gangue minerals [4-6].

Within the last decade, with the development of solvent-extraction and electrowinning processes for the treatment of nonsulfide zinc ores, there has been a renewed commercial interest for this type of mineralization throughout the world [2,3,7]. The commercial exploitation of nonsulfide deposits, commonly defined as "Zinc Oxides" or "Calamine" (nonsulfide $\mathrm{Zn}$ ore in carbonate rocks), is rapidly becoming an important source of metallic zinc. Moreover, it is expected that in the near future the annual production of zinc from these ores could exceed $10 \%$ of the global zinc metal production. Scientific researches is now focused not only on several economic "Zinc Oxide" deposits throughout the world [2,8-10] but also on older mining districts containing smaller and historically exploited deposits [11-13]. Compared to sulfide deposits, their main attraction lies in: a) their distinct scarcity or lack of $\mathrm{Pb}, \mathrm{S}$ and other undesirable elements, b) their relatively low-energy recovery by solvent extraction and electro-winning and c) the generation of higher economic value on site.

A wide series of papers focused on the traditional treatment of nonsulfides (including flotation processes), spanning the first seventy years of the last century [1416]. On the contrary, there are not as many recent published studies on the hydrometallurgical behavior of nonsulfide $\mathrm{Zn}$ minerals [6,17-20], because most mining companies are still in the experimentation phase.

The main goal of the present study is to separate the nonsulfide zinc from its associated gangues of Um Gheig mine through several beneficiation steps comprised of mineralogical investigation, liberation study and gravity separation by "shaking table".

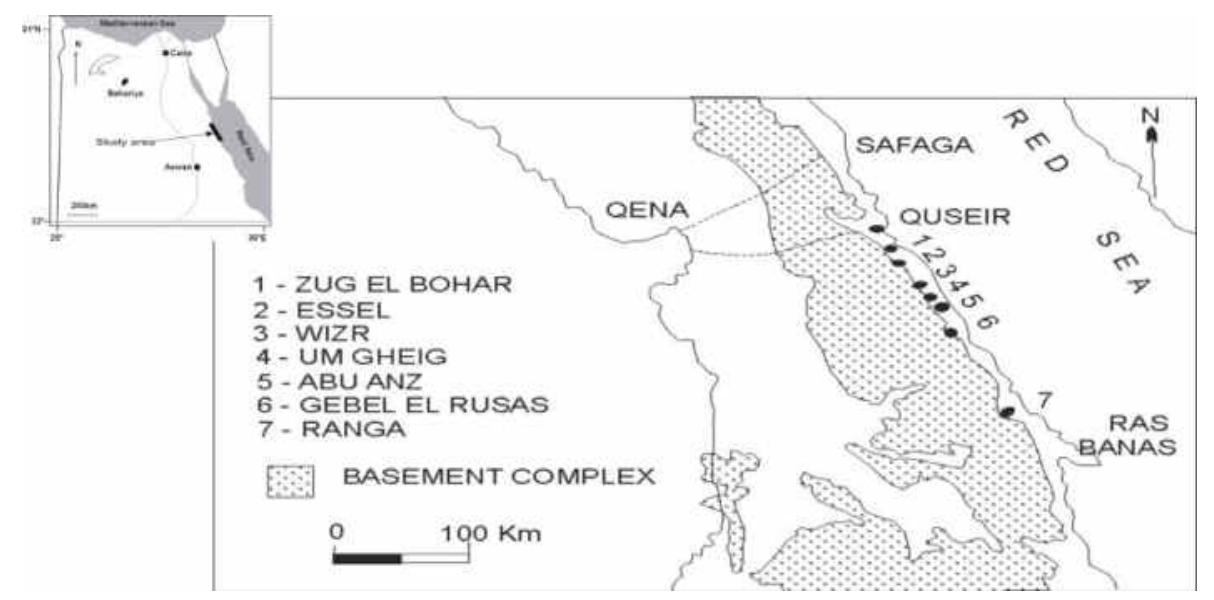

Fig.1. Location Map of the Zinc occurrences along the Red Sea coastal zone, Egypt. 


\section{EXPERIMENTAL WORK}

\subsection{Sample Preparation and Characterization}

A representative sample from Um Gheig mine, Egypt, was subjected to crushing by a "Denver" jaw crusher. Then the sample was divided into equal batches using coning and quartering method. One of these batches was further representatively divided into batches each of $5 \mathrm{~kg}$ weight. One of the latter was further sampled into $250 \mathrm{~g}$ batches using "Jone Riffle" sampler. A sample of them was ground and subjected for complete chemical analysis by X-ray fluorescence and X-ray diffraction as well as mineralogical analysis. Also ore preparation processes involved attrition scrubbing of the crushed ore to remove the dust and clay from the surface of the particles. Wet-dry size analysis using a series of ASTM standard sieves (i.e. 4, 3.327, 2.36, 1.16, 0.833, 0.589, 0.417, $0.298,0.208,0.106,0.071$, and $0.036 \mathrm{~mm}$ ) was performed. After screening, each size fraction was collected, weighed, and chemically analyzed for $\mathrm{ZnO} \%$. The degree of liberation was investigated, by using optical microscope; where each size fractions of mineral particles were mounted on thin sections and, later on, analyzed by optical microscope.

\subsection{Shaking Table Experiments}

A "Wilfley" shaking table was used in this study, Figure (2). Four parameters are studied; namely; inclination angle, stroke length, feed rate and water flow rate. The experiments were carried out at feed particle size $-0.125+0.08 \mathrm{~mm}$, which represent about $59.37 \%$ of the feed sample, where maximum liberation can be attained.

Fig. (2) Wifely Shaking Table Unit 1: Sample feeding box, 2: Washing water feeding box, 3 : Washing water, 4: Heavy products reservoirs,

5: Light products reservoirs

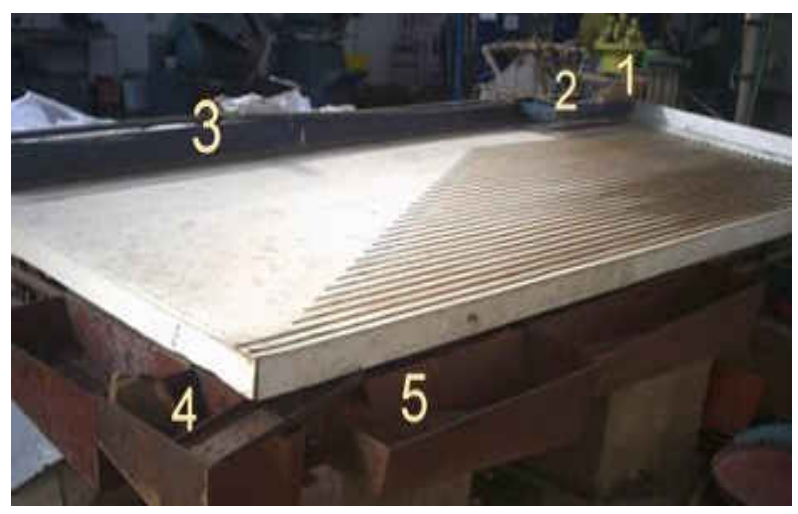

\section{RESULTS AND DISCUSSION}

\subsection{Sample Preparation}

Table (1) gives the results of the wet and dry size analysis of the representative sample whereas Table (2) gives the results of size and mineralogical analyses of its attrition scrubbed product. These results show the ore is generally friable in nature where it was noted that about $40.63 \%$ of the ore passed through the sieve $-0.036 \mathrm{~mm}$ after attrition scrubbing process. Mineralogical analysis (Table 2) indicated that most of such finest size fraction $(-0.036 \mathrm{~mm})$ is composed of hydrozincite due to the friability of hydrozincite in comparison to the other forms of zinc minerals and in turn most of 
hydrozincite rapidly affected by crushing and grinding processes than the other nonsulphide minerals.

Table (1):The results of the wet and dry size analysis of the sample

\begin{tabular}{|c||c|c|}
\hline \hline \multirow{2}{*}{$\begin{array}{c}\text { Size } \\
(\mathrm{mm})\end{array}$} & Dry analysis & Wet analysis \\
\cline { 2 - 3 } & Cum weight $\%$ & Cum weight $\%$ \\
\hline-0.036 & 4.14 & 5.81 \\
\hline 0.036 & 5.71 & 6.66 \\
\hline 0.071 & 7.22 & 8.29 \\
\hline 0.106 & 9.78 & 9.93 \\
\hline 0.208 & 11.96 & 11.49 \\
\hline 0.295 & 14.76 & 13.70 \\
\hline 0.417 & 18.38 & 16.35 \\
\hline 0.589 & 22.55 & 19.74 \\
\hline 0.833 & 27.72 & 24.63 \\
\hline 1.168 & 42.25 & 39.26 \\
\hline 2.36 & 56.26 & 53.89 \\
\hline 3.327 & 69.22 & 63.36 \\
\hline+4.00 & 100 & 100 \\
\hline
\end{tabular}

Table (2) Size and mineralogical analyses of attrition scrubbing product

\begin{tabular}{|c||c||c|c|c|c|c|}
\hline \hline \multirow{2}{*}{ Size, mm } & \multirow{2}{*}{$\begin{array}{c}\text { Neight } \\
\%\end{array}$} & \multicolumn{5}{|c|}{ Minerals \% } \\
\cline { 3 - 7 } & & Smithsonite & Hydrozincite & Hemimorphite & Calcite & Goethite \\
\hline \hline Bulk & 100 & 54.60 & 19.22 & 12.76 & 10.72 & 2.82 \\
\hline \hline+0.2 & 54.81 & 63.35 & 10.58 & 12.64 & 10.81 & 2.64 \\
\hline \hline$-0.2+0.1$ & 1.70 & 36.00 & 8.48 & 39.38 & 13.28 & 2.88 \\
\hline \hline$-0.1+0.036$ & 2.88 & 23.66 & 6.64 & 44.54 & 26.57 & 3.11 \\
\hline-0.036 & 40.63 & 30.55 & 56.26 & 2.84 & 6.35 & 4.01 \\
\hline \hline
\end{tabular}

\subsection{Characterization of Nonsulfide Zinc Ores}

Identification and characterization of minerals is of fundamental importance in the development and operation of mining and mineral processing systems [21], and it is very important in designing a suitable flow sheet for recovering the valuable metals. It is also critical in optimizing actual plant for improving performance [22]. The X-ray diffraction (XRD), chemical analysis, liberation study, and mineralogical investigation were used to determine the main zinc components of the ore and their associated gangues as well as the liberation degree which significantly affect the separation results in terms of grade and recovery. Table (3) gives the mineralogical and chemical composition of the non-sulphide zinc minerals and their associated gangue minerals. It shows that smithsonite is the major non-sulphide Zinc minerals where it represents about $50.74 \%$ by weight, whereas hydrozincite and hemimorphite represent $18.78 \%$ 
and $14.78 \%$ respectively. On the other hand calcite is the major gangue minerals (15.78\% in weight) and goethite $(2.86 \%)$, as showed inTable (3). This is also confirmed from the results of chemical analysis of the sample as shown in Table 3 . The sample contains about 47.5\% $\mathrm{ZnO}, 29.33 \% \mathrm{LOI}, 8.0 \% \mathrm{CaO}, 4.34 \% \mathrm{SiO}_{2}, 4.07 \%$ $\mathrm{Fe}_{2} \mathrm{O}_{3}$ and lower amount $(1.55 \%)$ of $\mathrm{PbO}$.

Table (3) The Mineralogical and chemical composition of the representative sample.

\begin{tabular}{|c|c|c|c|c|c|c|c|c|c|}
\hline \multicolumn{10}{|c|}{ Mineralogical composition \% } \\
\hline smithsonite & hydrozincite & hemin & phite & Calcite & & Goethite & Halit & & Quartz \\
\hline 50.74 & 18.78 & 14. & & 15.72 & & 2.86 & 0.48 & & 1.03 \\
\hline \multicolumn{10}{|c|}{ Chemical composition $\%$} \\
\hline $\mathrm{ZnO}$ & $\mathrm{CaO}$ & $\mathrm{Fe}_{2} \mathrm{O}_{3}$ & $\mathrm{SiO}_{2}$ & $\mathrm{MnO}$ & $\mathrm{SO}_{3}$ & $\mathrm{Cl}$ & $\mathrm{Na}_{2} \mathrm{O}$ & $\mathrm{MgO}$ & L.O.I \\
\hline 47.50 & 8.01 & 4.07 & 4.34 & 1.03 & 0.56 & 2.01 & 0.36 & 0.56 & 29.33 \\
\hline
\end{tabular}

L.O.I= loss on ignition at $1100^{\circ} \mathrm{C}$

There are two generations of smithsonite recognized under the polarized microscope and SEM. Smithsonite that occurs as dull, cryptocrystalline with no visible crystals (Fig. 3a). The second smithsonite generation (late smithsonite) occurs as clear rhombohedral crystals, precipitate in vugs and open space of the high grade ore (Fig. 4a). Hydrozincite occurs in different generations in the samples, the first hydrozincite generation occurs as veins growing in smithsonite; veins occur as thin, small veins (Fig. 3b), hydrozincite also occurs as nodules growing in the cavities between smithsonite (Fig. 3c) and botryodial hydrozincite (4b). Two hemimorphite generations could be observed. The first generation occurs as small concretions growing in finegrained smithsonite (Fig.3d). The second one appears as clear elongated crystals growing in veins and cavities (Fig. 3e). Calcite associated with supergene $\mathrm{Zn}-\mathrm{Pb}$ mineralization is relatively common, with crystals filling the vugs and open space in several samples (Fig. 3f), and also found as precipitate on the mineral surface.

Measurement of the degree of liberation of the minerals, a property directly related to the particle composition distribution as a function of particle size, was an extremely complex problem. Based on processing of optical or SEM images (back scattered electrons or X-ray spectra) are becoming faster and more efficient .

In this study, each size fractions of mineral particles were mounted on thin sections and, later on, analyzed by optical microscope. To achieve relatively high grades and recoveries in mineral processing; the valuable mineral must be individualized to almost mono-mineral particles by grinding operations prior to the physical concentration process.

Figures $5 \mathrm{a}$ and $5 \mathrm{~b}$ show complex interlocking and growth between nonsulphide $\mathrm{Zn}$ minerals (smithsonite, hydrozincite and hemimorphite) and calcite gangue minerals. Fig 5c shows that interlocking between non-sulphide $\mathrm{Zn}$ minerals and calcite is less complex "ternary particle". Fig 5d show that the grain boundaries of smithsonite, hydrozincite, hemimorphite and calcite have little interpenetration (usually binary interlocking), Figs 5 e and $5 f$ show that about more than of $90 \%$ fraction of the valuable non-sulphide $\mathrm{Zn}$ minerals (liberated) to consider a particle as "free". 
Higher degree of mineral liberation $(>90 \%)$ was attained at $0.106 \mathrm{~mm}$, as individual component minerals were distinctly separated. This was taken into consideration in preparing the feed samples for beneficiation experiments.
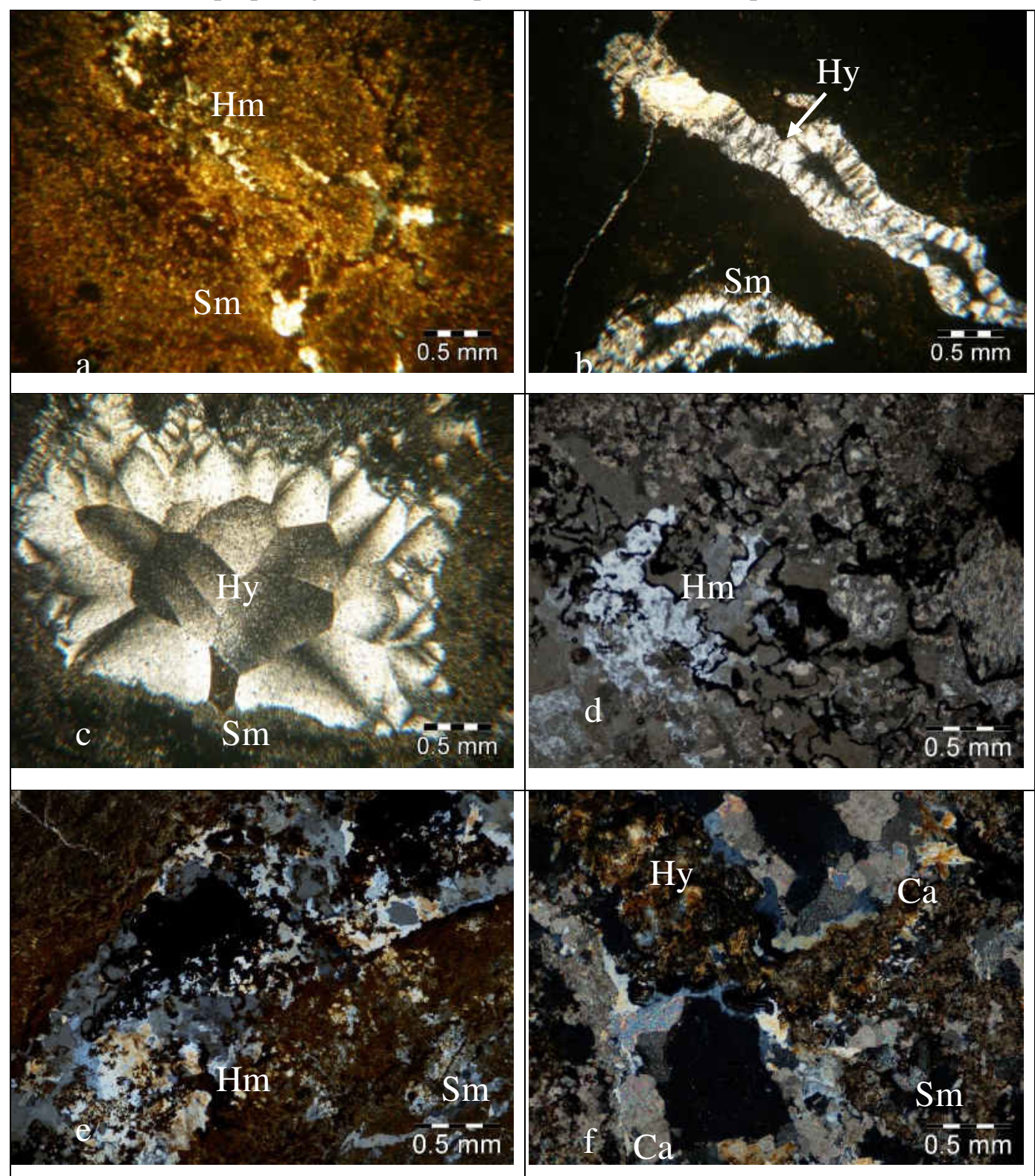

Fig.3. a) Smithsonite (sm) fine ground mass, cryptocrystalline, with no visible crystals. b) Hydrozincite $(\mathrm{Hy})$ veins growing in smithsonite mixed with iron oxide. c) Hydrozincite nodules growing in smithsonite. Note that, hydrozincite grade from fine small crystals to large hydrozincite crystals. d) hemimorphite $(\mathrm{Hm})$ with a dusty appearance inter growing in fine grained smithsonite.(first generation). e) Elongate hemimorphite veins growing in open space between smithsonite. (Second generation). f) Calcite (Ca) precipitate and filling in the vugs and open space. 

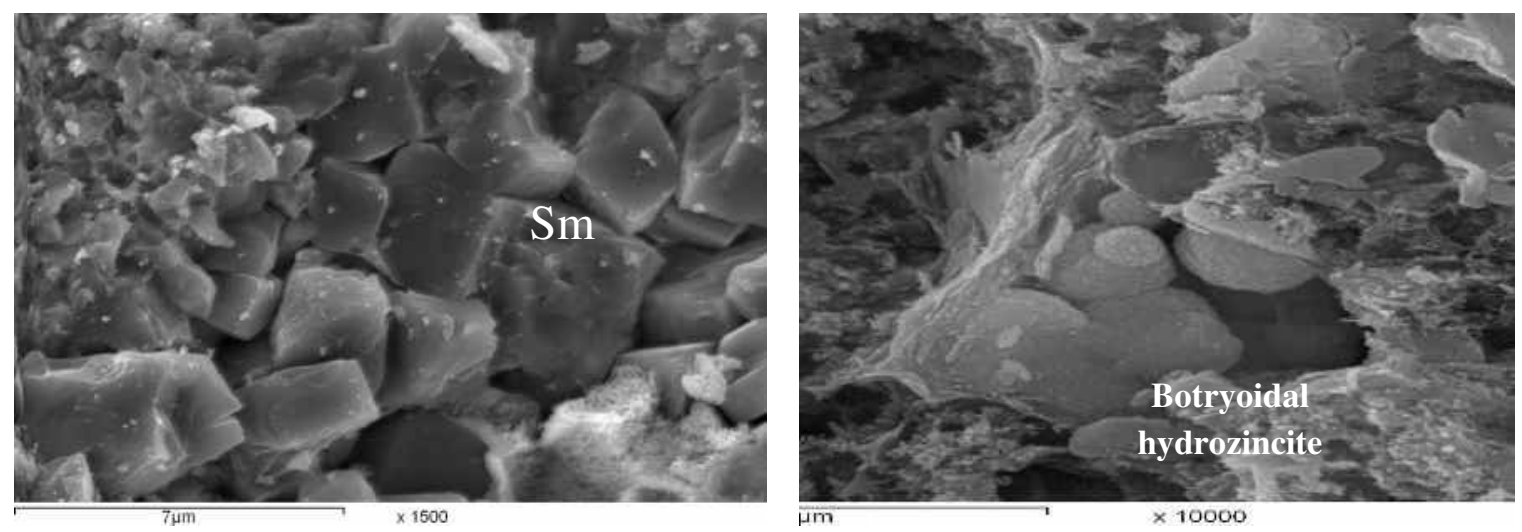

Fig.4. SEM of samples from Um Gheig nonsulfide deposits. a) Rhombohedra crystals of smithsonite (sm), filling vugs and open space of high grade ore sample. b) Botryoidal hydrozincite (Hy) in cavities between smithsonite.

\subsection{Shaking Table Separation Results}

Due to the difference in specific gravity between non-sulphide Zinc minerals (smithsonite, hydrozincite and hemimorphite with sp.gr.of 3.5 to 4.5 ) and the gangue calcite mineral (sp.gr 2.7) gravity technique is recommended for recovery of zinc minerals $[23,24)$.

\subsubsection{Effect of Inclination Angle}

Figure (6) illustrates the relation between inclination angle, grade and recovery of the shaking table at constant water flow rate $25 \mathrm{l} / \mathrm{min}$, feed rate $150 \mathrm{gm} / \mathrm{min}$, and stroke length $2.5 \mathrm{~cm}$. It is clearly noticed that, with increasing the inclination angle; the grade and recovery increase and reach to the maximum values at the inclination angle 4 degree. At such conditions, the concentrate product has $\mathrm{ZnO} \%$ and recovery of $62.30 \%$ and $92.03 \%$ respectively. On the other hand it is noticed that with increasing the inclination angle above 4 degree the grade and recovery are decreased. This is explained according to that the larger the inclination angle, the more difficult for good distribution of particles on the shaking table.

\subsection{Effect of Stroke Length (cm)}

Figure (7) shows the grade and recovery of zinc at different stroke lengths of shaking table and at constant water flow rate $25 \mathrm{l} / \mathrm{min}$, feed rate $150 \mathrm{gm} / \mathrm{min}$, and inclination angle 4 degree. It is noticed that good separation occurs at small values of the stroke length. This is due to that, any increase in the stroke length, the more disturbance of the particles occur on the shaking table and hence the more difficult separation. The most efficient stroke length is $2.5 \mathrm{~cm}$; at which a concentrate product with an assay of $60.22 \% \mathrm{ZnO}$, and a recovery of $91.12 \%$ was obtained. 

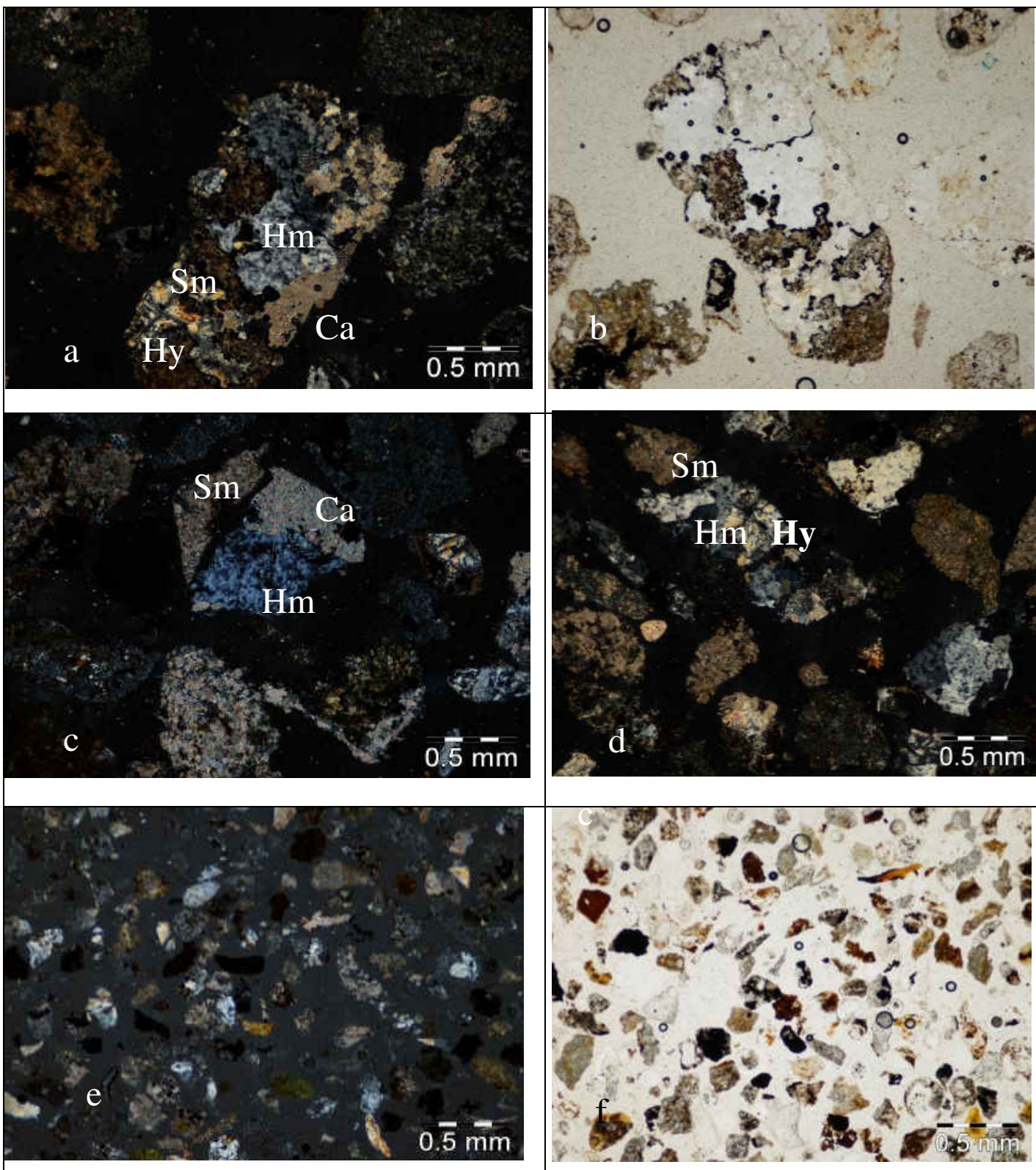

Fig.5. a) $0.833 \mathrm{~mm}$ size fraction shows (composite particale) complex interlocking and growth between non-sulphide $\mathrm{Zn}$ minerals (smithsonite, hydrozincite and hemimorphite) and calcite gangue minerals, under CN. b) Same photo in a under PPL. c) $0.589 \mathrm{~mm}$ size fraction shows ternary particles of smithsonite $(\mathrm{sm})$, hemimorphite $(\mathrm{Hm})$ and calcite $(\mathrm{ca})$. d) $0.417 \mathrm{~mm}$ size fraction less complex shows simple binary association of smithsonite $(\mathrm{sm})$, hemimorphite $(\mathrm{Hm})$, hydrozincite $(\mathrm{Hy})$ and calcite (ca). e) $0.106 \mathrm{~mm}$ size fraction show that the minerals are separated (free), liberation $>90 \%$. f) same Photo in e under PPL 


\subsubsection{Effect of Feed Rate ( $\mathrm{gm} / \mathrm{min})$}

Figure (8) shows the grade and recovery of zinc as a function of feed rates at constant water flow rate $25 \mathrm{l} / \mathrm{min}$, inclination angle 4 degree, and stroke length $2.5 \mathrm{~cm}$. It is obvious that the most efficient feed rate is $150 \mathrm{gm} / \mathrm{min}$; at which the concentrate product has an assay of $62.18 \% \mathrm{ZnO}$, and a recovery of $93.8 \%$. On the other hand, it is noticed that with increasing the feed rate over $150 \mathrm{gm} / \mathrm{min}$, both grade and recovery decrease in a great manner. This could be explained due to the larger the feed rate, the more crowding of particles on the shaking table, and hence the more difficult conditions of separation on the shaking table.

\subsubsection{Effect of Water Flow Rate (I/ min)}

Figure (9) shows the grade and recovery of zinc at different water flow rates and at constant feed rate $150 \mathrm{gm} / \mathrm{min}$, inclination angle 4 degree, and stroke length $2.5 \mathrm{~cm}$. It is obvious that the most efficient water flow rate is $25 \mathrm{l} / \mathrm{min}$; at which a concentrate product with an assay of $60.85 \% \mathrm{ZnO}$, and a recovery of $90.05 \%$ was obtained.

From the obtained results it can be seen that the best operating parameters to obtain a concentrate with high assay and recovery are at inclination angle (4 degree), stroke length $(2.5 \mathrm{~cm})$, feed rate $(150 \mathrm{gm} / \mathrm{min})$, and water flow rate $(25 \mathrm{~L} / \mathrm{min})$.

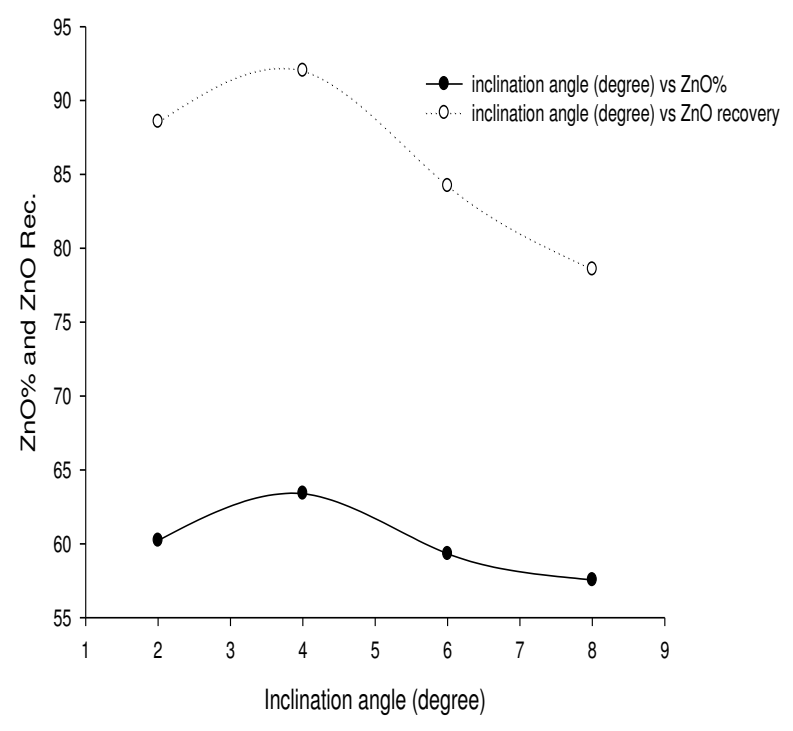

Fig (6) Inclination angle as a function of $\mathrm{ZnO} \%$ and Recovery, at constant water flow rate $=25 \mathrm{~L} / \mathrm{min}$, feed rate $=150$ $\mathrm{gm} / \mathrm{min}$ and stroke length $=2.5 \mathrm{~cm}$

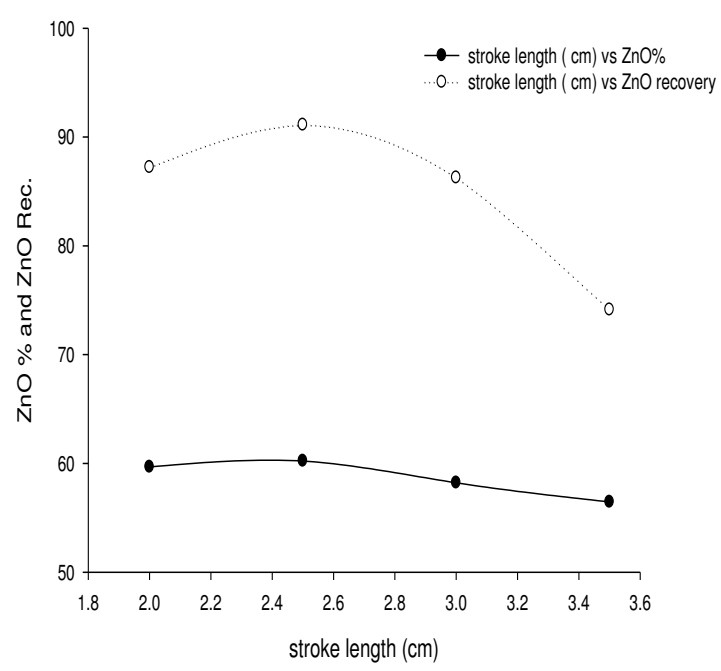

Fig (7) Stroke length as a function of $\mathrm{ZnO} \%$ and Recovery, at constant water flow rate $=25 \mathrm{~L} / \mathrm{min}$, feed rate $=150$ $\mathrm{gm} / \mathrm{min}$ and inclination angle $=4$ degree 

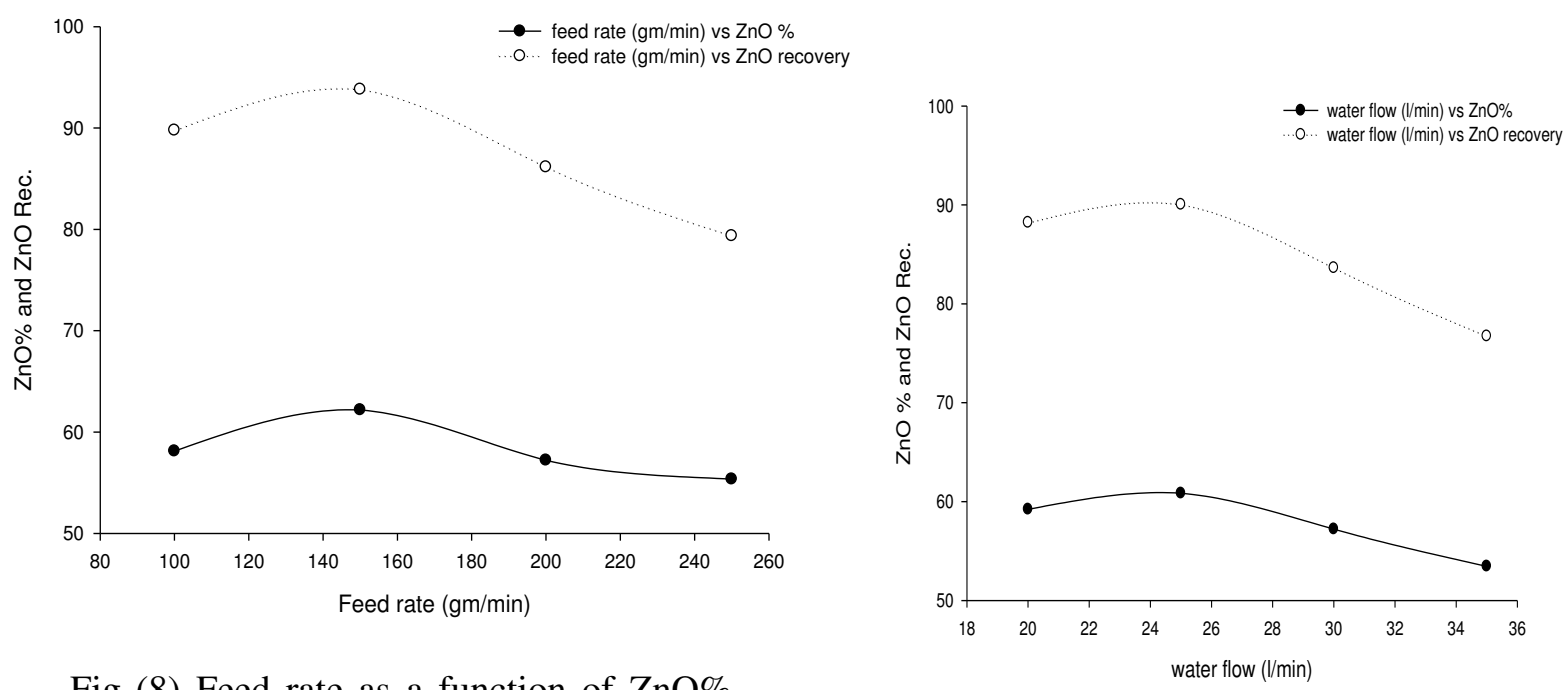

Fig (8) Feed rate as a function of $\mathrm{ZnO} \%$ and Recovery, at constant water flow rate $=$ $25 \mathrm{~L} / \mathrm{min}$, stroke length= $2.5 \mathrm{gm} / \mathrm{min}$ and inclination angle $=4^{\circ}$

Fig (9) Water flow rate as a function of grade and recovery at constant feed rate $=$ $150 \mathrm{gm} / \mathrm{min}$, stroke length $=2.5 \mathrm{gm} / \mathrm{min}$ and inclination angle $=4^{\circ}$

\section{CONCLUSIONS}

The nonsulfide Zinc mineral association at Um Gheig mine consists mainly of smithsonite, hydrozincite and hemimorphite, which replace both primary sulfide minerals and carbonate host rocks. Calcite and goethite are the main gangue minerals. Smithsonite $\left(\mathrm{ZnCO}_{3}\right)$ is the most abundant nonsulfide zinc mineral that occurs in two generations in the studied sample, the first generation of smithsonite, occurs as dull, cryptocrystalline with visible crystals, is finely intergrown with goethite. A late generation of smithsonite occurs as clear rhombohedral crystals. Hydrozincite $\left(\mathrm{Zn}_{5}\left(\mathrm{CO}_{3}\right)_{2}(\mathrm{OH})_{6}\right)$ is less abundant compared with smithsonite, occurs in different generations in the studied samples as veins, nodule and Botryodial. Hemimorphite $\mathrm{Zn}_{4} \mathrm{Si}_{2} \mathrm{O}_{7}(\mathrm{OH})_{2} \cdot \mathrm{H}_{2} \mathrm{O}$ quite abundant, occurring in at least two generations. A first generation occurs as small concretions with a dusty appearance growing in finegrained smithsonite. The second one appears as clear elongated crystals growing in veins and cavities.

The experimental beneficiation techniques involved crushing, grinding, and classification to prepare a feed suitable for the separation process. Gravity separation process using "shaking table" was applied to separate the zinc bearing minerals from their associated gangues.

Liberation study indicated that high degree of mineral liberation can be attained at $0.106 \mathrm{~mm}$ in size, where individual component are distinctly separated and in turn the shaking table experiments are applied on the feed size of $-0.125+0.080 \mathrm{~mm}$. Four parameters are studied, namely; inclination angle, stroke length, feed rate and water flow rate. 
The results show that the optimum parameters of the shaking table to obtain a concentrate of high grade and high recovery are at: inclination angle (4 degree), stroke length $(2.5 \mathrm{~cm})$, feed rate $(150 \mathrm{gm} / \mathrm{min})$, and water flow rate $(25 \mathrm{~L} / \mathrm{min})$. At such optimum conditions a grade of $60.85 \% \mathrm{ZnO}$ and recovery of $90.05 \%$ can be obtained from a head sample assaying $47.55 \% \mathrm{ZnO}$.

\section{REFERENCES}

1- El Aref, M.M. and Amstutz, G.C. :"Lead-zinc deposits along the Red Sea coast of Egypt, new observations and enetic models on the occurrences of Um Gheig, Wizr, Essel and ZugEl Bohar". Monogr. Ser. on Mineral Deposits, Borntraeger Stuttgart, 21, $103 \mathrm{p},(1983)$

2- Hitzman, M.W., Reynolds, N.A., Sangster, D.F., Allen, C.R., and Carman, C.: Classification, genesis, and exploration guides for non-sulfide zinc deposits", ECONOMIC GEOLOGY, Vol. 98, p. 685-714, (2003)

3- Large, D. : "The geology of non-sulphide zinc deposits-an overview", Erzmetall,Vol. 54, p. 264-276, (2003)

4- Boni, M. : "The Geology and Mineralogy of Nonsulfide Zinc Ore Deposits", Proceedings of LEAD and ZINC '05, Kyoto 17-19 October, pp. 1299-1314, (2005)

5- Woollett, A. : "The processing of non-sulphide zinc deposits", In: Boni, M., Gilg, H.A.(Eds.), European Science Foundation (ESF) Workshop on Nonsulfide $\mathrm{Zn}-\mathrm{Pb}$ Deposits, Iglesias, 21-23 April, Abstract 1 pp., (2005)

6- de Wet, K., and Singleton, J.D. : "Development of a viable process for the recovery of zinc from oxide ores. The Southern African Institute of Mining and Metallurgy, Proceedings of LEAD and ZINC '08, Durban, pp. 177-192 , (2008)

7- Boni, M. : "Non-sulfide zinc deposits: a new-(old) type of economic mineralization", SGA News Nr.15, pp. 1 and 6-11, August (2003)

8- Borg, G., Kärner, K., Buxton, M., Armstrong, R. and Schalk, W.V.D. : "Geology of the Skorpion supergene zinc deposit, southern Namibia ", Economic Geology Vol.98, 749-771, (2003).

9- Gilg, H.A., Allen, C., Balassone, G., Boni, M. and Moore, F. : "The 3-stage evolution of the Angouran Zn "oxide-sulfide deposit, Iran ", Seventh Biennial SGA Meeting "Mineral Exploration and Sustainable Development", Athens, Greece, August 24-28, 4pp,(2003)

10- Monteiro, L.V.S., Bettencourt, J.S., Caetano Juliani, C., and De Oliveira, T.F.: Geology, petrography, and mineral chemistry of the Vazante non-sulfide and Ambrósia and Fagundes sulfide-rich carbonate-hosted $\mathrm{Zn}-(\mathrm{Pb})$ deposits ", Minas Gerais, Brazil. Ore Geology Reviews Vol. 28, 201-234, (2006)

11- Boni, M., Gilg, H.A., Aversa, G., and Balassone, G.: "The "Calamine" of SW Sardinia (Italy): geology, mineralogy and stable isotope geochemistry of a supergene Zn-mineralization" , Economic Geology , Vol.98, 731-748, (2003)

12- Boni, M., and Large, D.: "Non-sulfide Zinc Mineralization in Europe: An Overview", Economic Geology, Vol. 98, No. 4, 2003, 715-729 , (2003)

13- Balassone, G., Rossi, M., Boni, M., Stanley, G.,and McDermott, P.: "Supergene nonsulfide $\mathrm{Zn}-\mathrm{Pb}$ ores at Silvermines and Galmoy (Ireland)" , In: Boni, M., Gilg, 
H.A. (Eds.), ESF Workshop on Nonsulfide Zn-Pb Deposits 21-23 April, Iglesias, Italy, pp. 5-6, (2005)

14- Rey, M., Sitia, G., Raffinot, P., and Formanek, V. : "The flotation of oxidized zinc ore", Transactions AIME Vol. 199, 416-420, (1954)

15- Billi, M., and Quai, V. : "Developments and results obtained in the treatment of zinc oxide ores at the AMMI mines" , VI International Mineral Processing Congress, Cannes, pp. 631-649, (1963)

16- Caproni, G., Ciccu, R., Ghiani, M., and Trudu, I. :"The processing of oxidized lead and zinc ores in the Campo Pisano and San Giovanni plants (Sardinia) ", In: Laskowski, J. (Ed.), Proc. 13th Int. Minerals Process. Cong., Processing of Oxidized and Mixed Oxide- Sulfide Lead-Zinc Ores, Warsaw, pp. 71-91, (1979)

17- Bodas, M.G. : "Hydrometallurgical treatment of zinc silicate ore from Thailand", Hydrometallurgy, Vol.40, 37-49, (1996)

18- Abdel-Aal, E.A.: "Kinetics of sulfuric acid leaching of low-grade zinc silicate ore", Hydrometallurgy Vol. 55, 247-254, (2000)

19- Loan, M., Newman, O.M.G., Cooper, R.M.G., Farrow, J.B.,and Parkinson, G.M. : "Defining the Para-goethite process for iron removal in zinc hydrometallurgy", Hydrometallurgy, Vol.81, 104-129, (2006)

20- Souza, A.D., Pina, P.S., Lima, E.V.O., Da Silva, C.A., and Leão, V.A. : "Kinetics of sulphuric acid leaching of a zinc silicate calcine ", Hydrometallurgy,Vol. 89, 337-345, (2007)

21- Hope, G.A., Woodsy, R., and Munce, C.G. : "Raman microprobe mineral identification", Miner. Eng.Vol.14 (12), 1565-1577, (2001)

22- Xiao, Z., and Laplante, A.R.: "Characterizing and recovering the platinum group minerals - a review", Miner. Eng.,Vol.17, 961-979, (2004)

23- Gupta, A. and Yan, D.S. : " Mineral processing design and operation", Gravity separation 494p., (2006)

24- Wills, B.A. and Tim Napier-Munn : "Wills' Mineral processing technology", (Seventh Edition), Gravity concentration, (2005). 


\section{توصيف وتركيز رواسب الزنك بمنطقة أم غيج بساحل البحر الأحمر بطرق الفصل بالجاذبية}

يهدف هذا البحث الى فصل رواسب الزنك بمنطقة أم غيج بساحل البحر الأحمر بمصر عن الثوائب بالبالبه

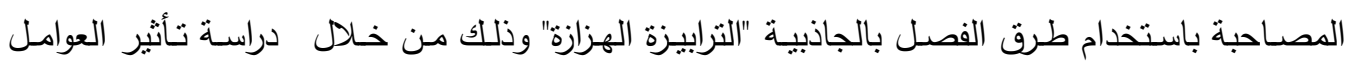
المختلفة التي نؤثر على عملية التزكيز للوصول الى الظروف المثلى لعملية الفصل.

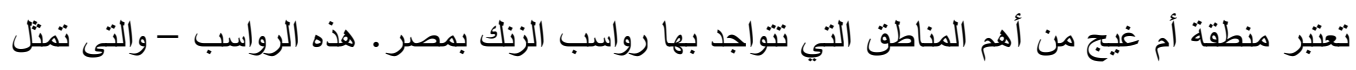

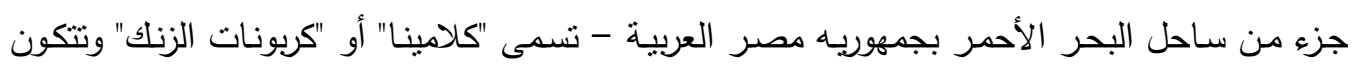

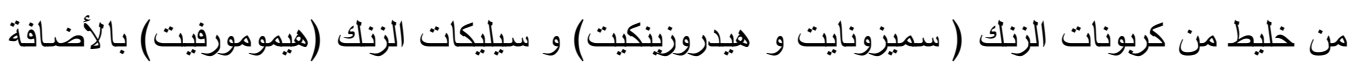
الى كميات مختلفة من معادن الرصاص والكالسيت و الجوتيت.

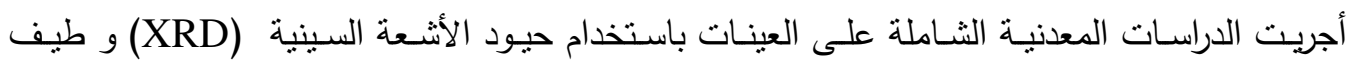

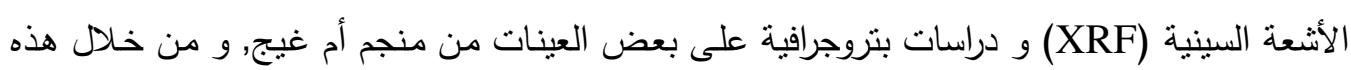

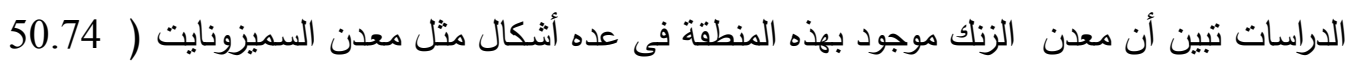

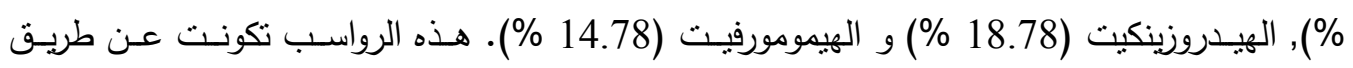

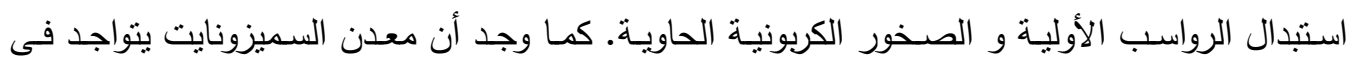

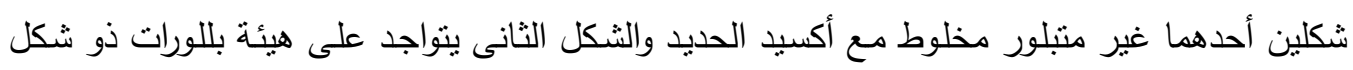

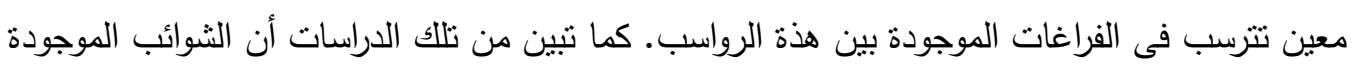

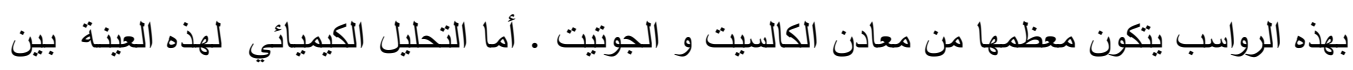
أنها تحتوى على 47.50 \% أكسيد زنك و 1.55 \% أكسيد رصاص و 29.28 \% و فا قد عند الحرق.

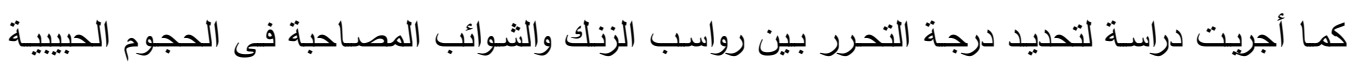

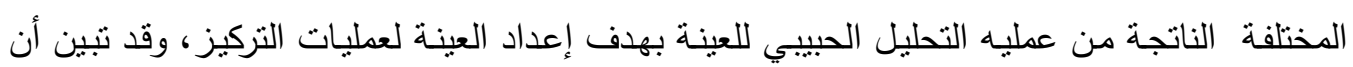
أفضل حجم حبيبي ينت عنده الفصل والحصول على أعلى درجة تحرر بين رواسب الزنك و الثوائب

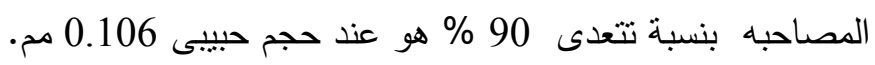

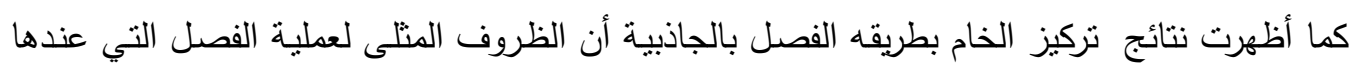

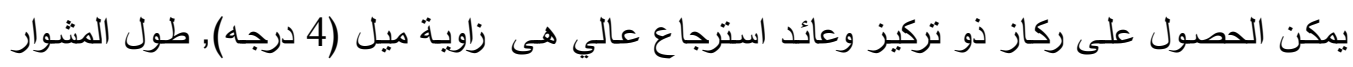

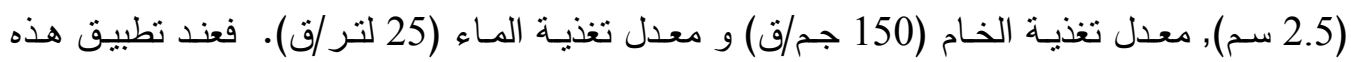

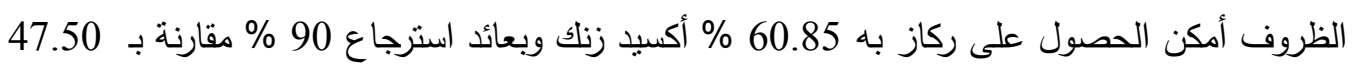
\% أكسيد زنك فى العينة الأصلية. 